\title{
KONTRIBUSI TRADISI HAROA \\ DALAM PENDIDIKAN KARAKTER MASYARAKAT \\ BUTON
}

\author{
Nurdin \\ Fakultas Ushuluddin, Adab, dan Dakwah IAIN Kendari \\ nurdinkarim@gmail.com
}

\begin{abstract}
This study aims to (1) find out how the harmonic tradition exists in Buton society, (2) know the tradition forms of Buton society, and (3) know the character values in the tradition of Buton society. This study uses a descriptive qualitative approach that describes the process of harmonic tradition implementation in Buton society. The data is obtained through observation, interview, and documentation. The data source consists of 15 people consisting of syara Masjid, customary leaders, and village and community leaders. Data analysis is undertaken by using Miles \& Huberman analysis model. The results showed that the implementation of the haroa is a hereditary tradition created by Buton society where the implementation is done from house to house, in the mosque, and in other places mutually agreed. The forms of haroa practice can be classified as follows: (a) haroa for the big days of Islam, such as isra'mi'raj, maulid of the Prophet Mauhammad Saw, Sha'ban, ramadhan, lailatul qadar night, feast of Eid fithri and Eid adha (b) haroa for syukuran / selamatan, (c) haroa for death (poalona mate). The character values contained in the tradition of the haroa are religiousity, gratitude, togetherness, love and affection, unity, help, care, deliberation, and tolerance.
\end{abstract}

Keywords: tradition of haroa, character education, community of Buton

\begin{abstract}
Abstrak
Penelitian ini bertujuan (1) untuk mengetahui bagaimana pelaksanaan tradisi haroa pada masyarakat Buton, (2) Untuk mengetahui bentuk-bentuk tradisi pada masyarakat Buton, (3) Untuk mengetahui nilai-nilai karakter pada tradisi haroa masyarakat Buton. Penelitian ini menggunakan pendekatan kualitatif deskripsitif yaitu mendeskripsikan proses pelaksanaan tradisi haroa pada masyarakat Buton. Teknik pengumpulan data dilakukan dengan menggunakan observasi, wawancara, dan dokumentasi. Instrumen penelitian ini adalah peneliti sendiri sebagai key instrumen, penunjukkan informan dilakukan secara purposive sampling dan bersifat snowball. Sumber data terdiri dari 15 orang yang terdiri dari syara Masjid, tokoh adat, pemerintah desa dan tokoh masyarakat. Analisis data dilakukan dengan menggunakan model analisis Miles \& Huberman yang diawali dari proses pengumpulan data, reduksi data, display data, dan pengujian keabsahan data/verifikasi. Hasil penelitian menunjukkan bahwa pelaksanaan haroa merupakan
\end{abstract}


tradisi yang turun temurun yang dilakukan masyarakat Buton dimana pelaksanaannya dilakukan dari rumah ke rumah, di Masjid, dan di tempat-tempat lain yang disepakati bersama. Adapun bentuk-bentuk pelaksanaan haroa dapat diklasifikasi sebagai berikut: (a) haroa memperingati hari-hari besar agama Islam, seperti isra'mi'raj, maulid Nabi Mauhammad Saw, Sya'ban, ramadhan, malam lailatul qadar, hari raya idul fithri dan idul adha (b) haroa syukuran/selamatan, (c) haroa kematian (poalona mate). Nilai-nilai karakter yang terkandung dalam tradisi haroa adalah religius, syukur, kebersamaan, cinta dan kasih sayang, persatuan, tolong menolong, peduli, musyawarah, toleransi.

\section{Kata kunci: tradisi haroa, pendidikan karakter, masyarakat Buton}

\section{A. PENDAhULUAN}

Bertitik tolak dari apa yang tengah dirasakan dan terjadi dalam kehidupan bangsa kita akhir-akhir ini, sungguh meresahkan pikiran kita semua. Perbedaan pandangan dan pendapat di antara elit politik, perbedaan sikap dan pilihan (contoh dalam pilkada DKI) di antara warga memicu lahirnya perpecahan dan bahkan disorientasi bangsa. Tidak tanggungtanggung yang menjadi salah satu pemicunya adalah masalah penistaan agama. Maka muncullah mobilisasi sentimen agama yang digencarkan kelompok-kelompok yang menggunakan label agama mampu menyedot energi sebagian masyarakat Islam untuk teryakinkan bahwa agama mereka (Islam) telah ternista oleh salah seorang calon gubernur. ${ }^{1}$ Nilai-nilai kebangsaan (pancasila) yang seharusnya menjadi rujukan dalam kehidupan berbangsa dan bernegara menjadi terabaikan dan bahkan tercabik-cabik, oleh Qurtuby telah terjadi isu agama politik, dan politik agama. ${ }^{2}$ Menyedihkan, tetapi itulah resiko dan konsekwensi perjalanan panjang dari sebuah negara demokratis dalam mencari jati diri sesungguhnya. Biasnya, disana-sini para elit politik kita saling menyalahkan, muncul fitnah sana-sini dan merasa paling benar. Ulama dan tokoh-tokoh agama yang seharusnya menjadi "soko guru" pendamai dan penyejuk hati rakyat turut andil dan terbawa-bawa. Rasa kepercayaanpun di antara pemerintah dan umarohmenjadi hampir sirna dan bahkan pupus, lahirlah krisis kepercayaan (trusth crises), krisis identitas (identity crises). ${ }^{3}$

${ }^{1}$ Heyder Affan,Seperti apa wajah politik Indonesia setelah Pilkada Jakarta berakhir,http://www.bbc.com/indonesia/indonesia-39626091, diakses: 7 Juni 2017.

2 Sumanto Al Qurtuby, Agama Politik dan Politik Agama, http://www.dw.com/id/agama-politik-dan-politik-agama/a-19131469, diakses 6 Juni 2017

${ }^{3}$ Imron Rasyidi, Krisis Identitas, http://imron46.blogspot.co.id/2012/07/krisisidentitas.html, diakses: 7 Juni 2017. Krisis identitas bukan bermakna orang yang tidak mengenal namanya, tetapi orang yang lupa fungsi dan perannya, sebagai efek atau dampak seseorang yang mengalami degradasi konsep diri yang terkikis oleh kritik, terkikis oleh 
Fenomena di atas menjadi persoalan serius dalam pembangunan karakter bangsa kita. Jujur, bahwa apa yang telah terjadi di bangsa kita dewasa ini, sesungguhnya bukanlah cerminan karakteristik dan karakter manusia berideologi pancasila yang mendiami bumi pertiwi. Karakter yang berlandaskan falsafah Pancasila maknanya adalah setiap aspek karakter harus dijiwai oleh kelima sila Pancasila secara utuh dan komprehensif yang dapat diuraikan sebagai berikut. Pertama, bangsa yang berketuhanan yang maha esa memiliki ciri manusia yang taat, tunduk dan patuh pada perintah sang Maha Kuasa. Kedua, bangsa yang menjunjung kemanusiaan yang adil dan beradab yaitu mamiliki ciri saling hormat menghormati, pengakuan atas kesamaan derajat, hak dan kewajiban, saling mengasihi, tenggang rasa, peduli, tidak semena-mena terhadap orang lain, menjunjung tinggi nilai kemanusiaan berani membela kebenaran dan keadilan, merasakan dirinya sebagai bagian dari seluruh warga bangsa dan umat menusia. Ketiga, bangsa yang mengedepankan persatuan dan kesatuan bangsa, yang bercirikan sikap menempatkan persatuan dan kesatuan, kepentingan, dan keselamatan bangsa di atas kepentingan peribadi atau golongan, bangsa dan negara yang berBhineka Tunggal Ika. Keempat, bangsa yang demokratis dan menjunjung tinggi hukum dan hak asasi manusia. Dan kelima, bangsa yang mengedepankan keadilan dan kesejahteraan. ${ }^{4}$ Inilah karakter bangsa Indonesia sesungguhnya, yang bersumber dari nilai-nilai falsafah bangsa (pancasila) untuk dibudayakan disetiap relung kehidupan warga negara Indonesia.

Indonesia yang memiliki keragaman budaya adalah merupakan kekayaan dan kearifan lokal (local wisdom $)^{5}$ dalam membangun karakter

berbagai komentar negatif, terkikis oleh masukan dan saran yang terkesan bagus, terkesan melenakan tetapi sebenarnya merusak konsep diri.

${ }^{4}$ Muchlas Samani dan Hariyanto, Konsep dan Model Pendidikan Karakter, (Bandung: PT. Remaja Rosdakarya, 2013), hh. 22-24

${ }^{5}$ Novan Ardy Wiyani, Membumikan Pendidikan karakter di SD: Konsep Praktek dan Strategi, (Jogyakarta: Ar-Ruzz Media, 2013), h. 95. Kearifan lokal terdiri dari dua kata yaitu kearifan (wisdom) dan lokal (local). Wisdom (kearifan) memiliki arti yang sama dengan kebijaksanaan, sedangkan local (lokal) memiliki arti setempat. Secara umum maka local wisdom (kearifan lokal) dapat dipahami sebagai gagasan setempat (local) yang bersifat bijaksana, penuh kearifan, bernilai baik, yang tertanam dan diikuti oleh anggota masyarakatnya. Sementara menurut Irianto dalam Novan menyatakan bahwa kearifan lokal adalah sikap, pandangan, dan kemampuan suatu komunitas di dalam mengelola lingkungan ruhani dan jasmaninya, yang memberikan kepada komunitas itu daya tahan dan daya tumbuh di dalam wilayah di mana komunitas itu berada. Dengan kata lain kearifan lokal adalah jawaban kreatif terhadap situasi geografis-geopolitis, historis dan situasional yang bersifat lokal. Dengan demikian kearifan lokal dapat dijadikan sebagai jembatan menghubungkan 
bangsa. Manusia Indonesia bebas mengembangkan setiap budaya yang dimilikinya sepanjang tidak bertentangan dengan nilai-nilai falsafah bangsa. Sebab tumbuh kembang karakter anak-anak bangsa salah satunya adalah bersumber dari nilai-nilai budaya masyarakat setempat. Sehingga Pengenalan nilai-nilai budaya, suku, bahasa, agama dan kepercayaan menjadi perekat dan tali pemersatu bangsa. Dan inilah idea, gagasan dasar dan citacita luhur para pendiri bangsa (founding father) ini, sehingga menjadikan pancasila ${ }^{6}$ sebagai ideologi negara. Soedarsono menyatakan bahwa Pancasila harus disepakati menjadi dasar negara, pandangan hidup bangsa, kepribadian bangsa, jiwa bangsa, tujuan yang akan dicapai, perjanjian luhur bangsa, asas kehidupan bermasyarakat, berbangsa dan bernegara, pengamalan pembangunan bangsa, dan jati diri bangsa. ${ }^{7}$ Dengan demikian, maka nilainilai tradisi, keragaman sosial, budaya, agama dan kepercayaan menjadi sumber utama yang mendorong lahirnya nilai-nilai karakter bangsa Indonesia yang berideologi pancasila. Dalam kaitan ini pula Soedarsono kembali menegaskan bahwa "kita harus tegas menolak adanya anggapan yang marak berkembang bahwa pancasila sudah tidak relevan lagi di alam modernisasi, reformasi, dan globalisasi sekarang ini". ${ }^{8}$ Pertanyaannya adalah dari mana memulai pembelajaran nilai-nilai karakter bangsa?

Untuk menjawab pertanyaan mendasar dari tulisan ini, ada tiga aspek pentingyang saling bertautan yaitu, aspek budaya, agama, dan nilai-nilai falsafah bangsa. ${ }^{9}$ Ketiga aspek tersebut merupakan bingkai dan sumber dasar utama pembangun nilai-nilai karakter, yang dijabarkan dalam proses pendidikan baik formal, informal maupun nonformal. Memang, tantangan saat ini dan ke depan adalah mencari strategi yang tepat untuk menempatkan pendidikan karakter sebagai suatu kekuatan bangsa. Salah satu pendiri bangsa Presiden Pertama Indonesia Soekarno menegaskan bahwa "Bangsa ini harus dibangun dengan mendahukan pembangunan karakter (character building) karena character building inilah yang akan membuat Indonesia menjadi bangsa yang besar, maju dan jaya, serta bermartabat. Kalau character building ini tidak dilakukan, maka bangsa Indonesia akan menjadi bangsa kuli. ${ }^{10}$ Oleh karena itu, kebijakan dan implementasi pendidikan yang

masa lalu dan masa sekarang, generasi nenek moyang dan generasi sekarang, demi menyiapkan masa depan dan generasi mendatang.

6 Muchlas Samani dan Hariyanto, Konsep dan Model Pendidikan Karakter, (Bandung: PT. Remaja Rosdakarya, 2013), h. 21.

${ }^{7}$ Soemarno Soedarsono, Karakter menuju Bangsa dari Gelap Menjadi Terang, (Jakarta: PT. Alex Media Komputindo, 2009), h. 10

${ }^{8}$ Ibid,-

${ }^{9}$ Muchlas Samani, op.cit, h. 21

${ }^{10}$ Ibid, hh. 1-2 
berbasis karakter menjadi sangat penting dan strategis dalam rangka membangun bangsa ini. Hal ini tentunya juga menuntut adanya dukungan yang kondusif dari pranata politik, sosial, dan budaya bangsa.

Realitas bangsa Indonesia dengan keaneragaman nilai dan budaya kehidupan bermasyarakat memerlukan keterbukaan untuk menjalani kehidupan bersama dengan melihat realitas plural yang terjadi. Oleh karena itu, pendidikan harus diletakkan pada posisi yang tepat, apalagi ketika menghadapi konflik yang berbasis pada ras, suku dan keagamaan. Pendidikan karakter bukanlah sekedar wacana tetapi realitas implementasinya haruslah merupakan keberpihakan yang cerdas untuk membangun keberadaban bangsa Indonesia. Kementerian Pendidikan Nasional misalnya, dalam proses pembelajaran di Sekolah pada masingmasing tingkat satuan pendidikan telah memiliki sejumlah kebijakan yang tertuang dalam Renstranya, menyangkut penyiapan peserta didik. Salah satu kebijakan itu adalah mengembangkan kurikulum pendidikan yang memberikan muatan soft skills yang meningkatkan akhlak mulia dan menumbuhkan karakter berbangsa dan bernegara. Kebijakan itu perlu ditanggapi dengan tindakan nyata berupa rancangan pendidikan karakter yang diimplementasikan hingga tataran praktis secara sistemik dan terorganisir. ${ }^{11}$

Dalam konteks kehidupan bermasyarakat, pengarusutamaan (meanstreaming) pelaksanaan pendidikan karakter salah satunya adalah melalui implementasi nilai-nilai budaya lokal (value local wisdom). Haroa adalah salah satu budaya lokal Buton yang sampai saat ini masih dilaksanakan oleh masyarakat Buton. Sebagai bentuk kearifan lokal, tradisi haroa telah diteliti oleh beberapa penulis sebelumnya. Penelitian sebelumnya yang mengkaji tentang budaya haroa diantaranya diungkapkan oleh Mahrudin bahwa "haroa bagi masyarakat Buton adalah merupakan media untuk menyelesaikan konflik". Argumentasi temuan penelitian ini menjelaskan bahwa tradisi haroa telah memfasilitasi pihak-pihak yang bertikai, yang berkonflik satu sama lain, yang menyebabkan putusnya hubungan silatur rahim, bahkan rentan menciptakan konflik yang berkepanjangan. Dengan tradisi haroa maka tercipta perdamaian, harmoni persaudaraan terajut kembali terutama kerekatan sanak keluarga, kerabat, handai taulan dan tetangga. ${ }^{12}$ Sedangakan Nurdin dalam penelitiannya pada masyarakat Muslim Marginal Buton di Kecamatan Talaga Raya menjelaskan

\footnotetext{
${ }^{11}$ Puskur Kemdiknas, Pengembangan Pendidikan Budaya dan Karakter Bangsa, (Jakarta: Kemdiknas, 2010), h. 3.

${ }^{12}$ Mahrudin, Tradisi Haroa Sebagai Media Resolusi Konflik pada Masyarakat Buton, Proceding AICIS Kementerian Agama RI tahun 2012
} 
bahwa "haroa merupakan salah satu media pendidikan Agama Islam bagi masyarakat Buton.Melalui haroaperingatan hari-hari besar Islam masyarakat mendapatkan pengetahuan, pendidikan, bimbingan dan penyuluhan dari para mubaligh tentang nilai-nilai ajaran Islam". ${ }^{13}$

Berdasarkan kontribusi tulisan di atas tentang tradisi haroa, tulisan ini fokus pada kajian kontribusi budaya haroa dalam pembangunan karakter masyarakat Buton. Masyarakat Buton dimana karakteristik penduduknya hidup secara plural, heterogen (suku, budaya, bahasa, etnik) sampai saat ini tetap hidup rukun (damai), toleran, tolong menolong, bersatu, dan peduli. Nilai-nilai karakter tersebut dibangun tidak terlepas dari nilai-nilai falsafah hidup orang Buton yaitu "Bolimo Karo Somanamo Lipu (rela mengorbankan diri demi kepentingan daerah/negeri)." ${ }^{14}$ Tulisan besar ini terpampang pada salah satu tugu ketika masuk di Pelabuhan Kota Bau-Bau. Setiap orang yang melintas pasti membaca tulisan tersebut meskipun tidak ditau maknanya. Tapi bagi masyarakat Buton, nilai-nilai tersebut mendarah daging dalam alur kehidupan, sebab nilai-nilai budaya tersebut diperkenalkan dan diajarkan orang tua sejak masih usia anak-anak.

Nilai-nilai budaya haroa disinyalir memiliki kontribusi dalam membangunperilaku/karakter masyarakat Buton seperti saling menghargai, mencintai, kebersamaan, gotong royong, bersatu, dan saling mengasihi. Nilai-nilai tersebut tidak terkerus oleh arus gelombang hidup medernisasi yang individualistik. Hal ini terlihat darirealitas hidup masyarakat Buton yang penuh bersahaja dan komitmen terhadap nilai-nilai integritas kebangsaan, semua itu tidak terlepas dari pengamalan nilai-nilai budaya lokal yang dimiliki.Oleh karena itu, maka tulisan ini akan mengkaji lebih mendalam kearifan lokal masyarakat Buton yang hadir dalam bentuk "tradisi haroa", yang dielaborasi dalam beberapa pertanyaan penelitian yaitu; (1) apa itu haroa dan bagaimana proses pelaksanaannya, (b) bagaimana bentukbentuk tradisi haroa, dan (3) nilai-nilai karakter apa saja yang terkandung dalam tradisi haroa dan bagaimana mempengaruhi perilaku masyarakat Buton.

${ }^{13}$ Nurdin, Tradisi Haroa Sebagai Media Pendidikan Agama Islam pada Muslim Marginal Buton, Lembaga Penelitian dan Pengabdian Kepada Masyarakat Institut Agam Islam Negeri Kendari tahun 2014.

${ }^{14}$ La Ode Turi, Budaya Lokal Dalam Pelaksanaan Manajemen Berbasis Sekolah: Studi Kualitatif pada SMP Negeri 7 Bau-Bau Keraton Buton Sulawesi Tenggara, (Jakarta: Disertasi PPs UNJ, 2005), h. 230. 
Penelitian ini menggunakan metode deskriptif kualitatif, ${ }^{15}$ dengan teknik pengumpulan data dilakukan dengan menggunakan observasi, ${ }^{16}$ wawancara, ${ }^{17}$ dan dokumentasi. ${ }^{18}$ Instrumen penelitian ini adalah peneliti sendiri sebagai key instrument. ${ }^{19}$ Penunjukkan informan dilakukan secara purposive sampling dan bersifat snowball. ${ }^{20}$ Sumber data penelitian ini terdiri dari tokoh agama (mokimu, moji, imamu, khatibi), dan tokoh adat. Analisis data dilakukan dengan menggunakan model analisis Miles \& Huberman yang diawali dari proses pengumpulan data, reduksi data, display data, dan pengujian keabsahan data/verifikasi. ${ }^{21}$ Tujuan penelitian ini dilakukan untuk mendeskripsikan kontribusi tradisi haroa sebagai salah satu pembingkai karakter masyarakat Buton.

\section{B. PROSES PELAKSANAAN HAROA}

Bagi masyarakat Buton "haroa" adalah merupakan salah satu tradisi yang sudah dilakukan oleh nenek moyang masyarakat Buton. Tradisi tersebut dilaksanakan secara turun-temurun dari generasi ke generasi sampai sekarang. Proses pelaksanaan tradisi haroa dilaksanakan warga dari rumah ke rumah. Dalam proses pelaksanaan haroa setiap rumah mempersiapkan berbagai macam kue-kue khas Suku Buton seperti pisang goreng (sanggara), cucur (cucuru), bolu, ngkaowi-owi (ubi jalar), onde-onde, baruasa, lapa-lapa, dan sebagainya. Kue-kue tersebut di letakkan di atas mampan (tempat kue) khas orang Buton. Kue-kue tersebut disajikan untuk tamu undangan yang diundang kerumah warga yang menyelenggarakan haroa. Selain warga sekitar sanak keluarga, kerabat, tetangga juga turut diundang untuk bersamasama menghadiri haroa. Apabila para undangan, tetangga dan kerabat sudah kumpul, acara haroa pun dimulai. Tradisi haroa dipimpin oleh salah seorang syara' masjid atau tokoh adat yang dipanggil oleh tuan rumah. Pada masyarakat Buton menyandang jabatan sebagai syara Masjid (sarana masigi) biasanya tergolong tokoh adat dan/atau pemuka agama (Islam). Sebab dalam

\footnotetext{
${ }^{15}$ John W. Creswell, Qualitative Inquiry \& Research Design: Choosing Among Five Approaches, Third edition, (California: Sage Publications, Inc, 2013), h. 117

${ }^{16}$ James P. Spradley, Participant Observation, (USA: holt Rinehart and Wiston, 1980), h. 73.

${ }^{17}$ Kristin G, Esterberg, Qualitative Methods in Social Research, (New York: Mc Graw Hill, 2002), h. 20

${ }^{18}$ Robert C. Bogdan dan Sari Knopp Biklen, Qualitative Research for Education an Introduction to Theories and Method, fifth edition, (USA: Pearson Education, Inc, 2007), hh. $133-138$

${ }^{19}$ John W. Creswell, op. cit, h. 14.

${ }^{20}$ Moleong, Penelitian Kualitatif (Jakarta: Prenada Media, 2014), h. 110

${ }^{21}$ Sugiyono, Metode Penelitian Kuantitatif Kualitatif dan $R \& D$, (Bandung: Alfabeta, 2007), hh. 246-252.
} 
pandangan masyarakat merekalah yang dipercaya dan diberikan amanah oleh masyarakat untuk mengendalikan ritual-ritual seperti haroa syukuran, haroa keagamaan, haroa kematian, dan sebagainya.

Menelusuri makna kata haroa, dalam Kamus Besar Bahasa Indonesia kata haroa berasal dari kata arwah yang berarti jiwa orang yang meninggal; roh, atau semangat. ${ }^{22}$ Dalam bahasa Arab kata haroa berasal dari kara ruh yang berarti jiwa, artinya memperingati jiwa orang yang sudah meninggal. ${ }^{23}$ Dalam kultur lokal (Buton) haroa bermakna suatu prosesi ritual yang diselenggarakan oleh keluarga tertentu baik sebagai bentuk kesyukuran atas nikmat dan karunia yang diberikan Tuhan yang Maha Kuasa maupun haroa yang bentuknya adalah haroa "kematian". Berdasarkan tinjauan secara etimologi, kedua makna kata haroa di atas pada prinsipnya memiliki makna generik yang sama yaitu menekankan pada jiwa (ruh) yaitu memperingati jiwa atau ruh seseorang yang sudah meninggal dunia. Sedangkan kata haroa yang berarti 'semangat' adalah erat kaitannya dengan semangat keluarga yang ditinggalkan oleh seseorang dalam keluarga yang mereka cintai. Dengan peristiwa kematian, keluarga tersebut merasa kehilangan semangat, merasa lemah dan lesu, merasa kurang motivasi akibat ditinggalkan oleh sanak keluarga yang dicintai. Sehingga keluarga yang ditinggalkan bersedih akibat musibah yang dialami. Jika ditinjau secara etimologis dan istilah, maka haroa bermakna tradisi yang diselenggarakan warga Buton secara turun-temurun dan menjadi salah satu media silaturahim keluarga baik yang bersifat haroa kematian maupun haroa yang keagamaan dan bentuk-bentuk syukuran lainnya.

\section{BENTUK-BENTUK TADISI "HAROA"}

Seiring dengan perkembangan dan kemajuan zaman, tradisi haroa dalam proses pelaksanaannya di masyarakat Buton secara umum masih bertahan sampai sekarang. Bahkan tradisi haroa tidak hanya diperingati dalam lingkup keluarga, tetapi dewasa ini sudah dilaksanakan pada momenmomen besar seperti pada penyelenggaraan pemilihan Kepala Daerah (pilkada), pemilihan kepala desa oleh kelompok-kelompok masyarakat maupun organisasi. Sebagai tradisi masyarakat Buton, tradisi haroa dalam proses perkembangannya dapat diklasifikasi sebagai berikut:

\section{C.1. Haroa Peringatan Hari-Hari Besar Agama Islam.}

22 Departemen Pendidikan Nasional, Kamus Besar Bahasa Indonesia (Jakarta: Gramedia, 2008), h. 89.

${ }^{23}$ Amri, Dosen Bahasa Arab IAIN Kendari, wawancara: Mei, 2017. 
Para ahli studi tentang keagamaan, pada akhirnya sepakat bahwa agama sebagai sumber nilai, sumber etika dan pandangan hidup ${ }^{24}$, yang dapat diperankan dalam kehidupan bermasyarakat dan berbangsa. Pemikiran ini didasarkan pada alasan karena agama mengandung beberapa faktor. Pertama; faktor kreatif yaitu ajaran agama dapat mendorong manusia melakukan kerja produktif. Kedua faktor inovatif, yaitu ajaran agama dapat melandasi cita-cita dan amal perbuatan manusia dalam seluruh aspek kehidupan. Ketiga faktor sublimatif, yaitu ajaran agama dapat meningkatkan dan mengkuduskan fenomena kegiatan manusia, tidak hanya hal keagamaan tapi juga yang berdimensi keduniaan. Keempat faktor integratif yaitu ajaran agama dapat mempersatukan sikap dan pandangan manusia serta aktifitasnya baik secara individual maupun kolektif dalam menghadapi berbagai tantangan hidup. ${ }^{25}$ Manusia butuh terhadap agama, selain karena agama menyediakan berbagai faktor tersebut, juga karena keyakinan keagamaan menyebabkan pengaruh-pengaruh positif yang luar biasa dipandang dari kemampuannya, mampu menciptakan kebahagiaan atau memperbaiki hubungan-hubungan sosial atau mengurangi, bahkan menghapuskan sama sekali kesulitan-kesulitan yang sebelumnya tak terhindarkan dalam system dunia ini.

Kebutuhan manusia terhadap agama semakin diperlukan dalam kehidupan modern yang ditandai oleh pola hidup materialistik, hedonistik, pragmatik, dan positifistik yang kesemuanya itu cenderung memuja dan mendewakan materi. Keadaan ini pada gilirannya membuat membuat manusia merasa kekeringan spiritual, hidup hampa, dan teralienasi (terasing) ${ }^{26}$. Manusia menjadi semacam sekrup dari sebuah mesin raksasa kehidupan. Ia telah kehilangan jati dirinya yang utuh dan terfragmentasi. Keadaan ini menyebabkan ia rapuh ketika menghadapi berbagai masalah yang tidak sepenuhnya dapat diatasi oleh materi. Terjadinya kemerosotan moral, konflik sosial, stress, cemas, gelisah, gangguan keamanan, dan berbagai gejala penyakit sosial dan kejiwaan yang selanjutnya memengaruhi pikiran dan perasaannya dalam melaksanakan tugas-tugas, jelas tidak dapat diatasi dengan materi, melainkan dengan kembali kepada ajaran agama.

Peran dan fungsi agama, sebagaimana tersebut di atas dijumpai pada semua agama baik agama yang diturunkan Allah Swt (agama samawi) maupun agama-agama yang tergolong agama hasil renungan intuisi manusia yang biasanya disebut agama wadh'i (agama budaya). Dalam Islam misalnya

${ }^{24} \mathrm{H}$. Abuddin Nata, Imu Pendidikan Islam dengan Pendekatan Multidisipliner, cet. II (Jakarta: RajaGrafindo Persada, 2010), h. 37

${ }^{25}$ Ibid,-

${ }^{26}$ Ibid., h. 39 
agama berfungsi sebagai $h u d a n^{27}$ yakni pembimbing dan pemberi petunjuk; liyukhrijakum min al-dzulumat ila al-nur (mengeluarkan manusia dari kegelapan jiwa kepada pencerahan dan ketenangan jiwa), syifa ${ }^{28}$ (sebagai obat penawar jiwa yang tegang, gelisah dan cemas; rahmat $^{29}$ sebagai kasih sayang Tuhan atas keterbatasan manusia, al-burhan sebagai bukti kekuasaan Tuhan; basyiran dan nadzira ${ }^{30}$ pemberi kabar gembira dan sebagai pemberi peringatan, dan al-furqan ${ }^{31}$ yang memisahkan antara yang haq dan yang bathil, dan masih banyak lagi.Nilai-nilai agama (Islam) tersebut di atas hadir dalam kehidupan manusia, termasuk hadir dalam budaya suatu masyarakat. Sehingga mudah bagi kita untuk menginternalisasi nilai-nilai agama kepada diri seseorang karena nilai-nilai tersebut juga menjadi nilai-nilai budaya yang dianut oleh orang tua dan suatu masyarakat. Atau sebaliknya, menarik benang merah nilai-nilai dari suatu budaya, tradisi,seperti tradisi harao bagi masyarakat Buton sebagai bagian dari pengembangan nilai-nilai agama, misalnya silaturahim, kebersamaan, persatuan, musyawarah, tolong menolong. Nilai-nilai tersebut juga merupakan ajaran agama Islam, sehingga dapat dikatakanbahwa terjadi sinkronisasi (kesejajaran) ${ }^{32}$ nilai-nilai agama dan budaya.

Masyarakat Buton yang mayoritas penduduknya beragama Islam, sangat konsisten memperingati (merayakan) datangnya bulan suci bagi umat Islam. Kedatangan bulan suci tersebut disambut dan dimeriahkan dengan tradisi haroa. Di antara bulan suci agama Islam yang dimaksud adalah bulan rajab (isra' mi'raj) dalam bahasa lokal disebut "rajabu", maulid Nabi Muhammad Saw (maludhu), sya'bani, quпиa (malam lailatul qadar) dimalam 17 bulan ramadhan. Disamping itu peringatan terhadap hari raya idul fithri dan hari raya haji atau kurban. Dalam kalender Islam (Buton)hari-hari besar umat Islam tersebut diperingati sebagai peristiwa yang sangat besejarah, sehingga masyarakat muslim Buton sangat menaruh perhatian untuk selalu diperingati. Pada momen seperti ini, dalam kultur masyarakat Buton diperingati dengan tradisi haroa yang diselenggarakan di rumah-rumah oleh warga, di sekolah-sekolah, dan bahkan diinstansi Pemerintah. Menurut Muhaimin peringatan hari-hari besar islam dalam kaitannya dengan pendidikan karakter antara lain berfungsi sebagai upaya untuk (1)

27 Departemen Agama RI,Al-Quran dan Terjemahnya, (Jakarta: Yayasan Penyelenggara Penterjemah/Pentafsir Al-Quran, 1971),h. 8.

${ }^{28}$ Ibid, h. 315

${ }^{29}$ Ibid, h. 508

${ }^{30}$ Ibid, h. 31

${ }^{31} \mathrm{Ibid}$, h.558.

32 Departemen Pendidikan Nasional,Kamus Besar Bahasa Indonesia, (Jakarta:Gramedia, 2008) 
mengenang, merefleksikan, memaknai dan mengambil hikmah serta manfaat dari momentum sejarah berkaitan dengan hari besar yang diperingati dalam dan menghubungkan keterkaitannya dengan kehidupan masa kini; (2) menjadikan sejarah sebagai laboratorium bagi upaya refleksi dan evaluasi diri. ${ }^{33}$ Oleh karena itu maka pendidikan karakter bagi masyarakat tidak selayaknya dimaknai dan diajarkan dengan cara yang sempit, ${ }^{34}$ tetapi menurut Mu'in, pendidikan karakter dalam konsep agama tidak melihat bahwa karakter yang ada dalam diri anak atau seseorang adalah produk dialektika dengan pengalaman historisnya dan sejarah hubungannya dengan orang lain.Keberagamaan yang dialami oleh seseorang semacam itu hanya akan menghasilkan sosok yang mengetahui "halal" dan "haram" berdasarkan teks yang ditafsirkan secara selek dan diseleksi atau ditafsirkan sesuai kepentingan. ${ }^{35}$

Melalui haroa peringatan hari-hari besar Islam, masyarakat Buton melakukan internalisasi/penanaman nilai-nilai karakter yang bersumber dari ajaran agama yang dianut yaitu Islam. Masyarakat sata sama lain berinteraksi, membangun komunikasi yang sudah putus, bermusyawarah, saling mengasihi, tolerasni, saling menyapa sebagai bentuk penghargaan dan kepedulian. Mengacu pada teori yang dikembangkan Muhaimin bahwa proses penanaman nilai-nilai pendidikan karakter dilakukan 3 (tiga) tahap yaitu, transformasi nilai, transaksi nilai, dan transinternalisasi nilai. ${ }^{36}$ Transformasi dan transaksi nilai merupakan muatan, konsep ide tentang nilai-nilai yang akan ditransformasikan dalam kehidupan. Sedangkan transinternalisasi merupakan sikap perbuatan dari konsep yang diterima yang terimplementasi dalam diri yang wujud dalam perilaku keseharianseseorang.

\section{C.2. Haroa Syukuran/Selamatan (Haroana Syukuru/Salama')}

Dalam tradisi masyarakat Buton hampir tidak ada peristiwa yang terjadi dalam diri keluarga maupun kelompok yang tidak diikuti dengan tradisi haroa. Tradisi haroa syukuran, biasanya dirayakan oleh keluarga yang sedang melakukan suatu hajatan tertentu atau selamatan. Misalnya; selamatan atas kelahiran anak, selamatan pindah rumah (menempati rumah baru), selamatan mendapatkan rezki, selamatan dari bencana, selamatan atas

${ }^{33}$ Asmaun Sahlan dan Angga Teguh Prastyo, Desain Pembelajaran Berbasis Karakter, (Jakarta: Ar-Ruzz Media, 2012), h. 37

${ }^{34}$ Ibid, h. 36

${ }^{35}$ Fatchul Mu'in, Pendidikan Karakter Konstuksi Teoretis dan Praktik Urgensi Pendidikan Progresif dan Revitalisasi Peran Guru dan Orang Tua (Yogyakarta: Ar-Ruzz Media, 2011), hh. 316-317

${ }^{36}$ Muhaimin, Strategi Belajar Mengajar (Surabaya: Citra Media, 2014), h. 153 
prestasi yang dicapai, dan haroa/syukuran mendapatkan amanah sebagai pejabat. Dalam salah satu wawancara dengan informan menjelaskan bahwa: "haroa syukuran (baca dho'a) merupakan kebiasaan masyarakat Buton sebagai wujud kesyukuran kami terhadap Allah Swt apabila kami mendapatkan rezki, anak kami selamat dari bencana, selamatan melahirkan, sehat setelah sakit keras, pindah rumah/memasuki rumah baru, mendapat amanah baru sebagai pejabat, dan sebagainya. ${ }^{37}$

Pandangan tersebut di atas merupakan refleksi karakter syukur (religius)sekaligus ungkapan rasa terimakasih yang dimiliki masyarakat Buton kepada Tuhan Yang Maha Kuasa atas berkah yang dianugrahkan. Dan wujud rasa syukur itu didudukkan dalam bentuk mengumpul sanak keluarga, kerabat dekat, tetangga, untuk berdo'a bersama menyukuri pemberian Allah Swt. Dalam al-Quran cukup banyak perintah Allah yang menjelaskan kepada hambanya untuk mensyukuri setiap pemberiannya. Seperti dalam al-Quran surat al-Baqarah ayat 152, 172 yaitu:

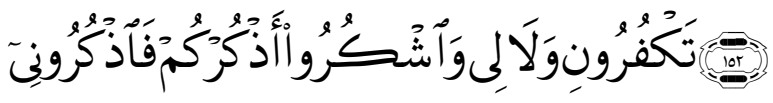

Artinya: "Karena itu, ingatlah kamu kepada-Ku niscaya aku ingat (pula) kepadamu, dan bersyukurlah kepada-Ku, dan janganlah kamu mengingkari (nikmat)-Ku. ${ }^{38}$

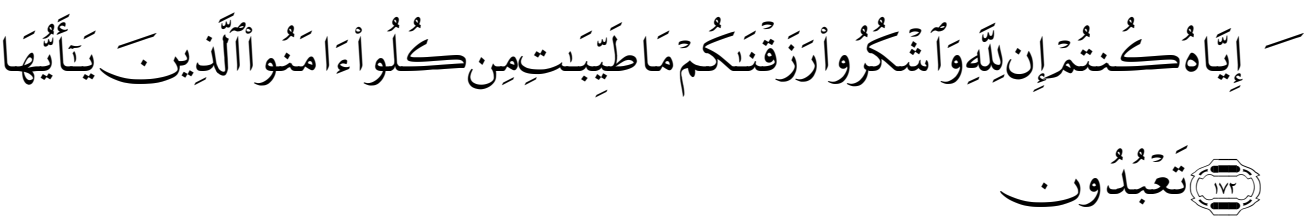

Artinya: "Hai orang-orang yang beriman, makanlah di antara rezki yang baik-baik yang Kami berikan kepadamu dan bersyukurlah kepada Allah, jika benar-benar kepada-Nya kamu menyembah. ${ }^{39}$

Dalam al-Quran Surat al-'ankabut ayat 17 juga dijelaskan sebagai berikut:

${ }^{37}$ H. Sidiq, Sarana Masigi (Imam Masjid), wawancara: Mei 2017

${ }^{38}$ Departemen Agama RI, op.cit, h.25

${ }^{39}$ Ibid, h.27 


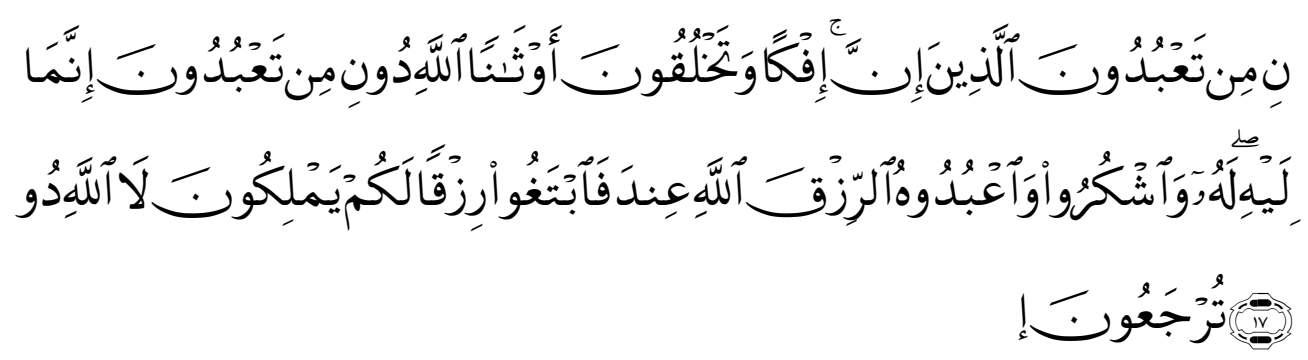

Artinya: "Sesungguhnya apa yang kamu sembah selain Allah itu adalah berhala, dan kamu membuat dusta. Sesungguhnya yang kamu sembah selain Allah itu tidak mampu memberikan rezki kepadamu; maka mintalah rezki itu di sisi Allah, dan sembahlah Dia dan bersyukurlah kepada-Nya, hanya kepada- Nyalah kamu akan dikembalikan. ${ }^{40}$

Demikian juga ancaman terhadap hambanya yang tidak mensyukuri karunia dan nikmat yang diberikan Allah, dalam al-Quran Allah menjelaskan dalam surat Ibrahim (14): 7 yaitu:

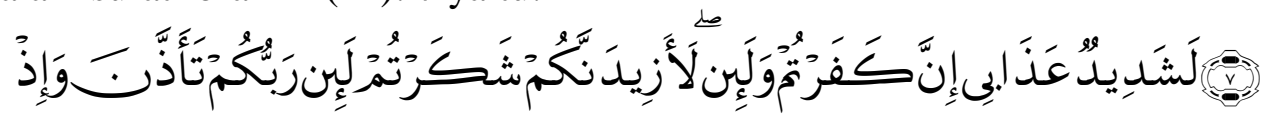

Artinya: "Dan (ingatlah juga), tatkala Tuhanmu memaklumkan; "Sesungguhnya jika kamu bersyukur, pasti Kami akan menambah (nikmat) kepadamu, dan jika kamu mengingkari (nikmat-Ku), maka sesungguhnya azab-Ku sangat pedih". ${ }^{41}$

\section{C.3. Haroa atas Kematian (Poalona Mate).}

Masyarakat muslim Buton memiliki kayakinan bahwa orang yang masih hidup dan kerabat yang meninggal masih memiliki hubungan. Dalam mengiringi kematian seseorang warga Buton merayakannya dengan sebuah tradisi yang disebut dengan poalo (bahasa lokal). Poalo adalah ritual yang dilakukan masyarakat Buton terhadap orang yang meninggal dunia, dan yang melakukan poalo adalah keluarga dekat. Tradisi poalo bagi masyarakat Buton umumnya dilaksanakan pada hari pertama kematian, hari ketujuh, hari keempat puluh, dan hari keseratus dua puluh. Klasifikasi hari-hari tersebut memiliki makna masing-masing dalam pengamalan keagamaan masyarakat Buton. Dalam pelaksanaan tradisi poalo bagi masyarakat Buton, seluruh atau sebagian kerabat dekat, handai taulan dan tetangga dekat diundang turut

\footnotetext{
${ }^{40}$ Ibid, h. 30

${ }^{41}$ Ibid, h. 56
} 
hadir. Tujuannya adalah untuk mengenang, mendoakan almarhum/almarhumah, menghibur keluarga yang ditinggalkan, mendengarkan tauziah agama Islam, dan silaturahim. Oleh karena itu, salah satu makna yang terkandung dalam tradisi haroa adalah mengirimkan do'a kepada para arwah (ruh) dalam bahasa lokal (sumanga). ${ }^{42}$ Jadi, berkumpulnya keluarga, kerabat dekat dan tetangga dalam tradisi haroa salah satu tujuannya adalah untuk berdoa bersama-sama meminta rahmat, keselamatan, berkah, ampunan, dan mengirimkan doa kepada para sumanga yang telah meninggal dunia.

\section{NILAI-NILAI KARAKTER DALAM TRADISI HAROA}

Pendidikan karakter merupakan upaya transformativ pengetahuan dan nilai dari nilai-nilai luhur yang bersumber dari agama, budaya dan kebangsaan. ${ }^{43}$ Secara demografi, masyarakat Buton merupakan salah satu daerah yang penduduknya terdiri dari berbagai macam suku, ragam budaya dan bahasa. Di antara etnik, suku yang adadi Buton adalah adalah etnik cina, Bali, Bugis-Makassar, Jawa, dan muna. Dari beragam suku, etnik dan budaya yang berbeda yang mendiami pulau Buton sampai sekarang ini hidup dengan rukun dan damai, penuh toleransi, pengertian dan kerjasama. Hal ini tidak lain dan tidak bukan karena filosofi kehidupan masyarakat buton yang senantiasa menghargai dan mengutamakan kepentingan daerah dari pada kepentingan individu. Inilah sebagian (elaborasi) makna filosofi "bolimo karo somanomo lipu”. Keragaman budaya yang hidup dan berkembang dari berbagai etnik menjadi kekuatan kearifan lokal bagi pembangunan daerah Buton. Demikian juga dengan budaya Buton sendiri seperti tradisi haroa, pekandekandea,menjadi kearifan lokal yang memiliki makna sejarah terutama dalam membangun karakter masyarakat Buton seperti kebersamaan, persatuan, cinta dan kasih sayang, peduli, musyawarah, menghargai, tolong menolong,dan toleransi antar suku, etnik dan budaya yang berbeda yang hidup di Buton. Inilah nilai-nilai kearifan lokal dari tradisi Buton yang masih bertahan sampai sekarang ini.

Pendidikan karakter adalah usaha penanaman nilai-nilai karakter tertentu kepada seseoranguntuk mewujudkan masyarakat Indonesia

\footnotetext{
${ }^{42}$ Sumanga dalam bahasa Buton adalah arwah orang-orang yang sudah meninggal dunia yaitu kakek, nenek, orang tua, anak, dan keluarga dekat. Setiap pelaksanaan haroa mereka selalu dikirimkan do'a supaya terjadi komunikasi yang berkesinambungan dengan keluarga yang masih hidup. Arwah mereka (kelaurga) yang telah meninggal akan mengganggu orang yang masih hidup kalau tidak dibacakan do'a, misalnya sakit-sakit. Mursal, Tokoh Adat dan Syara Masjid, wawancara: Mei 2017

${ }^{43}$ Amaun Sahlan \& Angga Teguh Prasetyo, Desain Pembelajaran Berbasis Karakter, (Jogyakarta: Ar-Ruzz Media, 2012), h. 33
} 
seutuhnya. Nilai-nilai karakter tersebut digali dari nilai-nilai luhur budaya bangsa, yaitu nilai ketuhanan, nilai terhadap diri pribadi, kesadaran terhadap lingkungan hidup, dan nilai kesusilaan terhadap sesama. Untuk itu, pendidikan karakter perlu berbasis pada budaya. Budaya berperan sebagai fondasi, nilai-nilai karakter sebagai badan bangunan, dan sebagai penegaknya diperlukan tiga soko-guru pendidikan karakter yaitu penanaman nilai-nilai karakter, pemberian teladan dan pembiasaan. ${ }^{44}$

Disadari bahwa karakter/akhlak/moral yang dimiliki manusia bersifat fleksibel atau luwes serta bisa diubah atau dibentuk. Karkater/akhlak/moral manusia suatu saat bisa baik tetapi pada saat yang lain sebalikya menjadi jahat. Perubahan ini tergantung bagaimana proses interaksi antara potensi dan sifat alami yang dimiliki manusiadengan kondisi lingkungannya, sosial budaya, pendidikan dan alam.Pendidikan karakter dilakukan melalui pendidikan nilai-nilai atau kebajikan yang menjadi nilai dasar karakter bangsa. Kebajikan yang menjadi atribut suatu karakter pada dasarnya adalah nilai. Oleh karena itu pendidikan karakter pada dasarnya adalah pengembangan nilai-nilai yang berasal dari pandangan hidup atau ideologi bangsa Indonesia, agama, budaya, dan nilai-nilai yang terumuskan dalam tujuan pendidikan nasional.

Nilai-nilai yang dikembangkan dalam pendidikan karakter di Indonesia diidentifikasi berasal dari empat sumber. Pertama agama, dimana masyarakat Indonesia merupakan masyarakat beragama, oleh karena itu kehidupan induvidu, masyarakat, dan bangsa selalu didasari pada ajaran agama dan kepercayaan yang dianut. Kedua, pancasila yaitu nilai-nilai yang terkandung dalam pancasila menjadi nilai-nilai yang mengatur kehidupan politik, hukum, ekonomi, kemsyarakatan, budaya dan seni. Pendidikan budaya dan karakter bangsa bertujuan mempersiapkan pesera didik menjadi warga negara yang lebih baik yaitu warga negar ayang memiliki kemampuan, kemauan dan menerapkan nilai-nilai pancasila dalam kehidupannya sebagai warga negara. Ketiga, budaya yaitu nilai-nilai yang dijadikan dasar dalam pemberian makna terhadap suatu konsep dan arti dalam komunikasi antar anggota masyarakat. Posisi budaya yang demikian penting dalam kehidupan mengharuskan budaya menjadi sumber nilai dalam pendidikan budaya dan karakter bangsa. Keempat yaitu tujuan pendidikan nasional yang berfungsi mengembangkan dan membentuk watak serta peradabanbangsa yang bermartabat dalam rangka mencerdasakan kehidupan bangsa, bertujuan untuk berkembangnya potensi peserta didik agar menjadi manusia yang beriman dan bertaqwa kepada Tuhan Yang Maha Esa, berakhlak mulia,

${ }^{44}$ Cece Rakhmat, Model Pendidikan Karakter Berbasis Budaya, Jurnal Pendidikan Ke-SD-an, Volume V No. 1 tahun 2014. 
sehat, berilmu, cakap, kreatif, mandiri dan menjadi warga negara yang demokratis dan bertanggung jawab. Tujuan tersebut dikembangkan dan dimiliki setiap warga negara melalui jalur satuan pendidikan diberbagai jenjang. ${ }^{45}$ Berdasarkan keempat sumber nilai di atas, teridentifikasi sejumlah nilai untuk pendidikan karakter yaitu: religius, jujur, toleransi, disiplin, kerja keras, kreatif, mandiri, demokratis, rasa ingin tahu, semangat kebangsaan, cinta tanah air, menghargai prestasi, bersahabat/komunikatif, cinta damai, gemar membaca, peduli lingkungan, peduli sosial, dan tanggung jawab. ${ }^{46}$

Salah satu media yang digunakan untuk membentuk karakter masyarakat Buton adalah melalui tradisi haroa. Nilai-nilai karakter yang terbangun melalui pelaksanaan tradisi haroa antara lain adalah rasa syukur kepada Allah Swt, dalam bahasa Nurcholish Madjid kemampuan seorang hamba untuk berterima kasih kepada Allah Sang Maha Pencipta. ${ }^{47}$. Hal ini juga diungkapkan oleh salah seorang informan bahwa "Kebiasaan orangorang tua kami dahulu kala sejak zaman kerajaan dan kesultanan Buton, setiap datangnya hari-hari baik agama Islam kami peringati (rayakan) dengan baca haroa.$^{48}$ Oleh karena itu tradisi haroa merupakan salah satu media yang digunakan oleh masyarakat untuk mengungkapkan rasa terimakasih dan syukur Masyarakat Buton atas karunia dan berkah yang diberikan Allah kepada hambanya.

Adapun karakter yang terbangun melalui pelaksanaan tradisi haroa adalah karakter saling menghargai, saling menghormati, toleransi, persaudaraan, kebersamaan, persatuan dan peduli terhadap sesama. Dalam tradisi haroa, antara sesama keluarga maupun tetangga saling undangmengundang. Warga berkeliling naik dan turun rumah, dari rumah ke rumah guna memenuhi undangan. Mereka yakin bahwa kebersamaan yang kokoh akan membangun nilai-nilai persatuan, dan akan melahirkan cinta dan kasih sayang yang harmonis dalam kehidupan sesama warga dalam kehidupan bermasyarakat. Demikian pula karakter kepedulian terhadap sesama warga, akan tumbuh saling tolong menolong dan bantu membantu, sebagai wujud rasa persaudaraan. Lickona dalam Koellhoffermengatakan bahwa "to develop his or her character, a person must understand core virtues, care

${ }^{45}$ Said Hamid Hasan, dkk, Pengembangan Pendidikan Budaya dan Karakter Bangsa, "Bahan Pelatihan Penguatan Metodologi Pembelajaran Berdasarkan Nilai-Nilai Budaya Untuk Membentuk Daya Saing dan Karakter Bangsa", (Jakarta: Puskur Balitbang Kemendiknas, 2010), h. 8

${ }^{46}$ Zubaedi, Desain Pendidikan Karakter Konsepsi dan Aplikasinya Dalam Lembaga Pendidikan Karakter, (Jakarta: Kencana Prenada Media Group, 2013), hh. 74-76

${ }^{47}$ Nurcholish Madjid, Islam Daktrin dan Peradaban, (Jakarta: Paramadina, 2013), h. 25

${ }^{48}$ H. Sidik, Imam Masjid Kecamatan Talaga Raya, wawancara: Mei 2017 
about them, and act upon them. ${ }^{49}$. Artinya bahwa apabila seseorang mau membangun karakternya, maka seseorang harus memahami inti kebajikan, peduli terhadap sesama, dan bertindak demi kebaikan bersama. Di sanalah nilai-nilai persaudaraan akan terwujud. Nilai-nilai persaudaraan juga dijelaskan dalam al-Quran surat al hujurat (49) ayat 10, Allah berfirman:

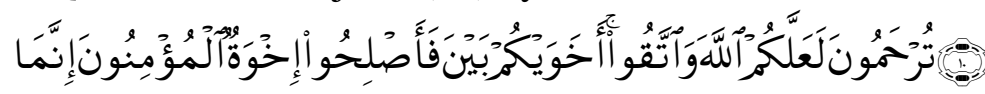

Artinya: "Orang-orang beriman itu Sesungguhnya bersaudara sebab itu damaikanlah (perbaikilah hubungan) antara kedua saudaramu itu dan takutlah terhadap Allah, supaya kamu mendapat rahmat."

Ayat tersebut di atas menegasikan bahwa tradisi haroa menjadi salah satu wahana untuk membangun karakter persaudaraan. Rusaknya persaudaraan akan berdampak pada keretakan hubungan antara sesama yang berdampak pada rusaknya tatanan kehidupan sosial dalam kehidupan masyarakat. Oleh karena itu, maka persaudaraan harus dibangun di atas toleransi di antara sesama. Haroa membangun karakter toleransi, artinya bahwa untuk menjadi orang yang toleran kita harus berusaha menerima orang lain, terlepas dari ras, agama, jenis kelamin, kelas, latar belakang budaya mereka, kemampuan atau cacat, atau karakteristik lain. Toleransiberarti berusaha untuk memahami dan menghormati orang-orang yangberbeda dari diri kita dan mengakui bahwa semua orang memilikihak untuk hidup dan memiliki tempat yang sama dalam masyarakat. ${ }^{51}$ Paling tidak jika kita tidak setuju dengan sudut pandang orang lain, agama, atausifatnya, kita dapat menunjukkan sikap simpati terhadap keyakinan mereka. Orang toleran terbuka untukide-ide baru, bersedia untuk belajar dari orang lain, dan menolak stereotiptentang berbagai kelompok orang. Inilah nilai-nilai toleransi yang ditanamkan dalam tradisi haroa, sehingga kebersamaan atas dasar keadilan dapat terbangun.

\section{E. PENUTUP}

Pelaksanaan haroa merupakan tradisi yang turun temurun yang dilakukan masyarakat muslim Buton yang pelaksnaannya dilakukan dari rumah ke rumah, di Masjid, dan di tempat-tempat lain yang disepakati

${ }^{49}$ Tara Tomczyk, Koellhoffer, Character Education: Being Fair and Honest

(New York: Chelsea House

Publishing, 2009), h. 9

${ }^{50}$ Departemen Agama RI, op.cit, h. 1076.

${ }^{51}$ Tara Tomczyk, Koellhoffer, op.cit, h. 17. 
bersama. Bentuk-bentuk pelaksanaan haroa secara garis besar dapat diklasifikasi sebagai berikut: (a) haroa memperingati hari-hari besar keagamaan (Islam), (b) haroa syukuran/selamatan, (c) haroa kematian. Sementara itu, nilai-nilai pendidikan karakter yang terkandung dalam tradisi haroa Buton adalah religius, persatuan, kebersamaan, musyawarah, peduli, cinta dan kasih sayang, tolong menolong, dan toleransi.

\section{DAFTAR PUSTAKA}

Biklen, Knopp Sari dan Bogdan, Robert C. Qualitative Research for Education an Introduction to Theories and Method, fifth edition. USA: Pearson Education, Inc, 2007.

Creswell, John W. Qualitative Inquiry \& Research Design: Choosing Among Five Approaches, Third edition. California: Sage Publications, Inc, 2013.

Departemen Agama RI. Al-Quran dan Terjemahnya. Jakarta: Yayasan Penyelenggara dan Pencetak Al-Quran, 1970.

Departemen Pendidikan Nasional. Kamus Besar Bahasa Indonesia. Jakarta: Gramedia, 2008.

Esterberg, Kristin G. Qualitative Methods in Social Research. New York: Mc Graw Hill, 2002.

Hariyanto, Samani Muchlas. Konsep dan Model Pendidikan Karakter. Bandung: PT. Remaja Rosdakarya, 2013.

Hasan, Hamid, Said, dkk. Pengembangan Pendidikan Budaya dan Karakter Bangsa. "Bahan Pelatihan Penguatan Metodologi Pembelajaran Berdasarkan Nilai-Nilai Budaya Untuk Membentuk Daya Saing dan Karakter Bangsa”, Jakarta: Puskur Balitbang Kemendiknas, 2010.

Koellhoffer, Tara Tomczyk. Character Education: Being Fair and Honest, New York: Chelsea HousePublishing, 2009.

Madjid, Nurcholish. Islam Daktrin dan Peradaban. Jakarta: Paramadina, 2013.

Mahrudin. Tradisi Haroa Sebagai Media Resolusi Konflik pada Masyarakat Buton. Proceding AICIS Kementerian Agama RI tahun 2012.

Mu'in, Fatchul. Pendidikan Karakter Konstuksi Teoretis dan Praktik Urgensi Pendidikan Progresif dan Revitalisasi Peran Guru dan Orang Tua. Yogyakarta: Ar-Ruzz Media, 2011.

Muhaimin. Strategi Belajar Mengajar. Surabaya: Citra Media, 2014. Moleong, Lexy J. Penelitian Kualitatif. Jakarta: Prenada Media, 2014.

Nata, H. Abuddin. Imu Pendidikan Islam dengan Pendekatan Multidisipliner, cet. II. Jakarta: RajaGrafindo Persada, 2010. 
Nurdin. Tradisi Haroa Sebagai Media Pendidikan Agama Islam pada Muslim Marginal Buton. Lembaga Penelitian dan Pengabdian Kepada Masyarakat Institut Agam Islam Negeri Kendari tahun 2014. Prastyo, Teguh Angga\& Sahlan, Asmaun. Desain Pembelajaran Berbasis Karakter. Jakarta: Ar-Ruzz Media, 2012.

Rakhmat, Cece. "Model Pendidikan Karakter Berbasis Budaya". Jurnal Pendidikan Ke-SD-an, Volume V No. 1 tahun 2014.

Soedarsono, Soemarno. Karakter Menuju Bangsa dari Gelap Menjadi Terang. Jakarta: PT. Alex Media Komputindo, 2009.

Spradley, James P. Participant Observation. USA: holt Rinehart and Wiston, 1980.

Sugiyono. Metode Penelitian Kuantitatif Kualitatif dan R\&D. Bandung: Alfabeta, 2007.

Turi, La Ode. Budaya Lokal Dalam Pelaksanaan Manajemen Berbasis Sekolah: Studi Kualitatif pada SMP Negeri 7 Bau-Bau Keraton Buton Sulawesi Tenggara. Jakarta: Disertasi PPs UNJ, 2005.

Zubaedi. Desain Pendidikan Karakter Konsepsi dan Aplikasinya Dalam Lembaga Pendidikan Karakter. Jakarta: Kencana Prenada Media Group, 2013.

\section{Website;}

Affan, Heyder. Seperti apa wajah politik Indonesia setelah Pilkada Jakarta berakhir. $\quad$ http://www.bbc.com/indonesia/indonesia-39626091, diakses: 7 Juni 2017.

Sumanto Al Qurtuby, Agama Politik dan Politik Agama, http://www.dw.com/id/agama-politik-dan-politik-agama/a19131469, diakses 6 Juni 2017 